\title{
Nitrite-dependent anaerobic methane oxidizing bacteria along the water level fluctuation zone of the Three Gorges Reservoir
}

\author{
Yu Wang ${ }^{1}$ • Pei Huang ${ }^{1}$ - Fei Ye ${ }^{1}$ - Yi Jiang ${ }^{1} \cdot$ Liyan Song ${ }^{1}$. \\ Huub J. M. Op den Camp ${ }^{2}$ Guibing $\mathrm{Zhu}^{3}$ - Shengjun $\mathrm{Wu}^{1}$
}

Received: 9 August 2015 /Revised: 5 October 2015 / Accepted: 12 October 2015 /Published online: 29 October 2015

(C) Springer-Verlag Berlin Heidelberg 2015

\begin{abstract}
The nitrite-dependent anaerobic methane oxidation (n-damo) mediated by "Candidatus Methylomirabilis oxyfera" connects the biogeochemical carbon and nitrogen cycles in a novel way. Many environments have been reported to harbor such organism being slow-growing and oxygensensitive anaerobes. Here, we focused on the population of $\mathrm{n}$-damo bacteria in a fluctuating habitat being the wetland in the water level fluctuation zone (WLFZ) of the Three Gorges Reservoir (TGR) in China. A molecular approach demonstrated positive amplifications when targeting the functional $\mathrm{pmoA}$ gene only in the lower sites which endured longer flooding time in an elevation gradient. Only 1 operational taxonomic unit (OTU) in the lower elevation zone targeting the $16 \mathrm{~S}$ ribosomal RNA (rRNA) gene was clustering into the NC-10 group a, which is presumed to be the true n-damo group. Moreover, a relatively low level of diversity was observed in this study. The abundances were as low as $4.7 \times 10^{2}$ to $1.5 \times 10^{3}$ copies $\mathrm{g}^{-1}$ dry soil $(\mathrm{ds})$ in the initial stage, which were almost the lowest reported. However, an increase was observed $\left(3.2 \times 10^{3}\right.$ to $5.3 \times 10^{4}$ copies $\left.\mathrm{g}^{-1} \mathrm{ds}\right)$ after nearly
\end{abstract}

Electronic supplementary material The online version of this article (doi:10.1007/s00253-015-7083-2) contains supplementary material, which is available to authorized users.

Shengjun $\mathrm{Wu}$

wsj@cigit.ac.cn

1 Chongqing Institute of Green and Intelligent Technology, Chinese Academy of Sciences, Chongqing 400714, China

2 Department of Microbiology, IWWR, Radboud University Nijmegen, Nijmegen 6525AJ, the Netherlands

3 Key Laboratory of Drinking Water Science and Technology, Research Center for Eco-Environmental Sciences, Chinese Academy of Sciences, Beijing 100085, China
6 months of flooding. Intriguingly, the abundance of n-damo bacteria correlated positively with the accumulated flooding time (AFT). The current study revealed that $\mathrm{n}$-damo bacteria can be detected in a fluctuating environment and the sites with longer flooding time seem to be preferred habitats. The water flooding may be the principal factor in this ecosystem by creating anoxic condition. The wide range of such habitats suggests a high potential of n-damo bacteria to play a key role in natural $\mathrm{CH}_{4}$ consumption.

Keywords Nitrite-dependent anaerobic methane oxidation . M. oxyfera-like bacteria - Water level fluctuation zone .

Three gorges reservoir $\cdot$ Water flooding

\section{Introduction}

Methane $\left(\mathrm{CH}_{4}\right)$ is a strong greenhouse gas, which is about 75 and 25 times more powerful at warming the atmosphere than carbon dioxide $\left(\mathrm{CO}_{2}\right)$ on 20 and 100 years time scale, respectively (Solomon et al. 2007). It is well acknowledged that water reservoirs are significant sources of $\mathrm{CH}_{4}$ (Rudd et al. 1993). Following the rising of the water level, large areas of wetlands are formed along the coast of these reservoirs. The organic carbon that was previously stored in plant and soil would be decomposed and converted to $\mathrm{CH}_{4}$ by methanogens (St. Louis et al. 2000). However, the transport pathway and the process of $\mathrm{CH}_{4}$ oxidation in anoxic layers, rather than just the population of methanogens, control the rate of $\mathrm{CH}_{4}$ emission (Joabsson et al. 1999).

It was estimated that about $60 \%$ of the $\mathrm{CH}_{4}$ consumption relied on microbial oxidation by aerobic or anaerobic methanotrophic bacteria and archaea. Anaerobic oxidation of methane (AOM) was shown to be coupled to the reduction of sulfate (Boetius et al. 2000; Milucka et al. 2012), nitrate 
(Haroon et al. 2013), manganese and iron oxides (Beal et al. 2009), and nitrite (Ettwig et al. 2010). The AOM is performed by either a consortium of bacteria and archaea, by the archaea themselves, or by Methylomirabilis oxyfera-like bacteria, belonging to the NC10 phylum (Ettwig et al. 2009). The energy yields of the AOM coupled to nitrate or nitrite as electron acceptors are substantially higher compared to sulfate, allowing these reactions to take place at lower substrate concentrations (Thauer and Shima 2008). Although data point to an intra-aerobic metabolism, the biochemical mechanism of nitrite-dependent anaerobic methane oxidation (n-damo), mediated by "Candidatus Methylomirabilis oxyfera," is still not well understood because of the difficulty to enrich these types of bacteria (Ettwig et al. 2010; Ettwig et al. 2009; Raghoebarsing et al. 2006). With the development of molecular biomarkers (Ettwig et al. 2009; Luesken et al. 2011) for ndamo bacteria, several ecosystems have been reported to harbor such organism, including peatland (Zhu et al. 2012), estuary (Shen et al. 2014a), paddy fields (Shen et al. 2014b; Wang et al. 2012; Zhou et al. 2014), sediment of freshwater lake (Kojima et al. 2012), river (Shen et al. 2014b), the South China Sea (Chen et al. 2015a; Chen et al. 2014), freshwater (Hu et al. 2014b) and coastal mangrove wetland (Chen et al. 2015b), and bioreactor (Hu et al. 2014b). In these habitats, the stable environment where there is a prolonged time for the bacterial population to develop (Dalsgaard et al. 2005) is crucial to n-damo bacteria which grow very slowly.

In the present study, we focused on the community of ndamo bacteria in a fluctuating habitat being the wetland in the water level fluctuation zone (WLFZ) of the Three Gorges Reservoir (TGR) in China. This wetland undergoes seasonal flooding due to the artificial regulation of the water level (145-175 m) (Fig. 1). Moreover, the water level rises to its highest point in winter and drops to its lowest level in summer, which is reverse to the fluctuation of natural water bodies. The unique and complex environmental conditions in the WLFZ of the TGR make it an ideal habitat to study the distribution of n-damo bacteria in nature and the response to a changing environment. The objective of this study was to investigate the spatial-temporal distribution of $n$-damo bacteria in the WLFZ of the TGR and to reveal its response to a fluctuating environment.

\section{Materials and methods}

\section{Site description and sampling}

The TGR is the largest hydroelectric project in China. The reservoir located between $28^{\circ} 32^{\prime} \mathrm{N}$ to $31^{\circ} 43^{\prime} \mathrm{N}$ and $105^{\circ}$ $49^{\prime} \mathrm{E}$ to $111^{\circ} 39^{\prime} \mathrm{E}$ with a total area of $1084 \mathrm{~km}^{2}$ under full operation (Fig. 1). For the purpose of flood control, navigation, and power generation, the water level is kept at $145 \mathrm{~m}$ during the flooding season (June-August) and increased to $175 \mathrm{~m}$ after the flooding season (October) (China Three Gorges Corporation 2015). As a consequence, the WLFZ is strongly influenced by the fluctuation of water level, resulting in periodic submergence and exposure to air (Fig. 1).

A typical WLFZ area (31 $\left.09^{\prime} 19^{\prime \prime} \mathrm{N}, 108^{\circ} 33^{\prime} 43^{\prime \prime} \mathrm{E}\right)$ was selected in this study. Considering the impact of water flooding to soil biogeochemistry, samples were taken at two dates, October 11, 2013 (water lever at about $169 \mathrm{~m}$ ), and April 1, 2014 (water level at about $161 \mathrm{~m}$ ), representing the initial stage and the later stage of water flooding, respectively. The samples were collected at 5-m elevation intervals, ranging from 150 to $175 \mathrm{~m}$. To avoid the abandoned farm land, the positions of sediment sites were marked in May and June of 2013 when the water was maintained at a low level. During the first sampling in 2013, six samples were taken and four of them were sediment samples (under the water level) at 150-, $155-, 160-$, and $165-\mathrm{m}$ elevations. During the sampling of 2014, three of them were sediment samples at 150-, 155-, and 160-m elevations. All others samples were soil samples (taken above the water level). The sediments were sampled from a boat with a Petersen grab and the surface soil samples $(0-10 \mathrm{~cm})$ were taken with a stainless steel core sampler. Five samples were collected for each site. Samples were kept in sterile plastic bags, sealed, and maintained on ice during transportation. At the laboratory, each sample was separated into subsamples, one was stored at $-20^{\circ} \mathrm{C}$ for DNA extraction and downstream analyses and the other one was stored at $4{ }^{\circ} \mathrm{C}$ for chemical analyses.

\section{Chemical analysis}

Soil $\mathrm{pH}$ was measured after shaking with water at a soil/water ratio of 1:5 and soil moisture was measured gravimetrically. Nitrogen- and carbon-related chemical parameters were measured in this study. Into $50 \mathrm{ml} 2 \mathrm{M} \mathrm{KCl}$ solution, 10-g fresh soil or sediment was added and the mixture was shaken at $200 \mathrm{rpm}$ for $1 \mathrm{~h}$. After shaking, the resulting solution was filtered and ammonium $\left(\mathrm{NH}_{4}{ }^{+}\right)$and nitrate $\left(\mathrm{NO}_{3}{ }^{-}\right)$were determined by flow injection analysis (FIA Star 5000, FOSS Tecator, Sweden). The detection limits were 0.03 and $0.01 \mathrm{mg} \mathrm{kg}^{-1}$, respectively. Nitrite was determined using the $\mathrm{N}$-(1-naphthyl) ethylenediamine dihydrochloride-based spectrophotometric method by reading the absorbance at $540 \mathrm{~nm}$. Total carbon (TC), total nitrogen (TN), and total sulfur (TS) were measured by an element analyzer (Vario EL cube, Elementar, Germany). Soil organic matter (OM) was measured through $\mathrm{LOI}_{550}$ (loss on ignition at $550{ }^{\circ} \mathrm{C}$ ). Ferrous iron $\left(\mathrm{Fe}^{2+}\right)$ and ferric iron $\left(\mathrm{Fe}^{3+}\right)$ were measured according to standard methods (Bao 2005). All analyses were carried out in triplicate. 

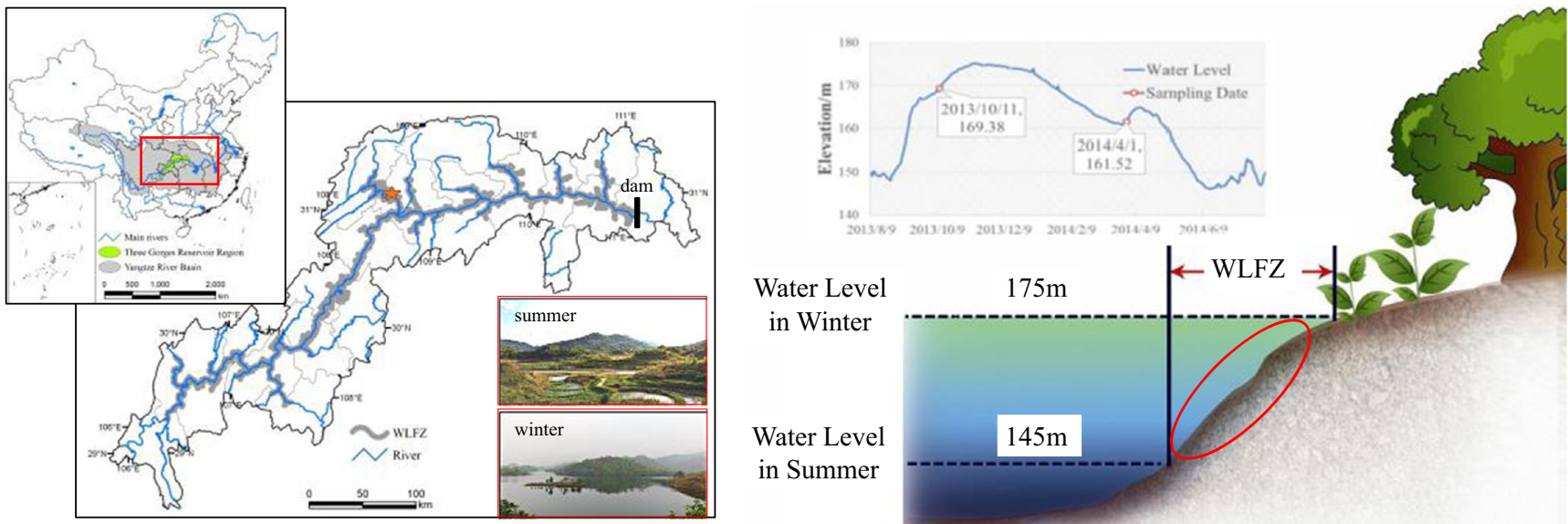

Fig. 1 Map of the Three Gorges Reservoir showing the location of the sampling site and respective landscape in summer and winter (left); sketch map showing the formation of the WLFZ and the fluctuation of water level in the TGR with circles indicating the sampling time (right)

\section{DNA extraction and PCR amplification}

DNA from soil/sediment samples were extracted according to the manufacturer's instruction using the PowerSoil DNA Isolation Kit (Mobio, USA). The DNA concentration was determined using a NanoVue Plus Spectrophotometer (GE Healthcare, UK) and the DNA quality was checked by $1 \%$ (weight/volume) agarose gel electrophoresis. The extracted DNA was stored at $-20{ }^{\circ} \mathrm{C}$ for further analyses.

Nested approaches were employed to amplify the $p m o A$ gene (first round with the primer pair of A189_b-cmo682, followed by the primer pair of cmo182-cmo568) with the following protocol: initial melting step at $95{ }^{\circ} \mathrm{C}$ for $5 \mathrm{~min}$, followed by 35 cycles of denaturation at $95{ }^{\circ} \mathrm{C}$ for $1 \mathrm{~min}$, annealing at $55^{\circ} \mathrm{C}$ (first round) or $59{ }^{\circ} \mathrm{C}$ (second round) for $1 \mathrm{~min}$, elongation at $72{ }^{\circ} \mathrm{C}$ for $1 \mathrm{~min}$, and a final elongation step at $72{ }^{\circ} \mathrm{C}$ for $10 \mathrm{~min}$ (Luesken et al. 2011). The $16 \mathrm{~S}$ ribosomal RNA (rRNA) gene (first round with the primer pair of $202 \mathrm{~F}-630 \mathrm{R}$, followed by the primer pair of $\mathrm{p} 1 \mathrm{~F}-\mathrm{p} 2 \mathrm{R}$ ) was amplified with the following protocol: initial melting step at $95{ }^{\circ} \mathrm{C}$ for $5 \mathrm{~min}$, followed by 35 cycles of denaturation at $95{ }^{\circ} \mathrm{C}$ for $1 \mathrm{~min}$, annealing at $55^{\circ} \mathrm{C}$ (first round) or $57{ }^{\circ} \mathrm{C}$ (second round) for $1 \mathrm{~min}$, elongation at $72^{\circ} \mathrm{C}$ for $1 \mathrm{~min}$, and a final elongation step at $72{ }^{\circ} \mathrm{C}$ for $10 \mathrm{~min}$ (Ettwig et al. 2009; Juretschko et al. 1998). The sequences of primers used in this study are listed in Table 1. PCR was performed with the GoTaq ${ }^{\circledR}$ Green Master Mix (Promega, USA).

\section{Quantitative PCR analysis}

To avoid the potential biases of the observed abundance, the quantitative PCR of n-damo bacteria targeting the 16S rRNA gene was performed with two specific primer pairs of $\mathrm{p} 1 \mathrm{~F}-$ p1R and p2F-p2R (Ettwig et al. 2009), respectively. An initial denaturing step of $95^{\circ} \mathrm{C}$ for 3 min was followed by 40 cycles of denaturation at $95{ }^{\circ} \mathrm{C}$ for $1 \mathrm{~min}$, annealing at $63{ }^{\circ} \mathrm{C}$ for
$1 \mathrm{~min}$, and elongation at $72^{\circ} \mathrm{C}$ for $1 \mathrm{~min}$. The final elongation step was 5 min at $72{ }^{\circ} \mathrm{C}$. Primer pair $8 \mathrm{~F}$-Eub338-IR targeting the bacterial 16S rRNA gene was used for the quantification of total bacteria (Amann et al. 1990; Juretschko et al. 1998). A similar protocol was applied (see above) except an annealing temperature of $55^{\circ} \mathrm{C}$. Positive clones of $16 \mathrm{~S}$ rRNA gene of ndamo bacteria and general bacteria were selected to isolate the plasmids containing corresponding inserts using a GeneJet Plasmid Miniprep Kit (Fermentas MBI, Lithuania). Tenfold serial dilutions of plasmids were used to construct the standard curves. The concentrations of plasmids were determined by a NanoVue Plus Spectrophotometer (GE Healthcare, UK) and used for the calculation of gene copy numbers. Quantitative PCR amplification was performed in a total volume of $20 \mu \mathrm{l}$ with a SYBR Green qPCR kit (Takara, Japan) in triplicate on Realplex2 real-time PCR instrument (Eppendorf, Germany). PCR reaction mixtures contained Premix Ex Taq $10 \mu$, forward and reverse primers $0.5 \mu \mathrm{l}$ of each $(10 \mu \mathrm{M})$, and $2 \mu \mathrm{l}(5-$ $10 \mathrm{ng} / \mu \mathrm{l}) \mathrm{DNA}$ as template. Only results with amplification efficiency and correlation coefficient above $95 \%$ and 0.98 were used.

\section{Cloning, sequencing, and phylogenetic analysis}

Both 16S rRNA and pmoA genes were cloned and sequenced. PCR products (two samples in 2013, four samples in 2014) were purified and ligated into the pGEM-T Easy cloning vector (Promega, USA) and then transformed to Escherichia coli JM109 competent cells. About 70 clones of each library were obtained. Sequences were divided into operational taxonomic units (OTUs) by setting a 0.03 cutoff (equivalent to $97 \%$ identity) using MOTHUR program (Schloss et al. 2009). Phylogenetic analysis of the 16S rRNA and pmoA genes was conducted in MEGA 5.0 software by neighbor-joining with the Jukes-Cantor correction (Tamura et al. 2011). Sequences obtained in this 
Table 1 The primers and thermal profiles used in this study

\begin{tabular}{|c|c|c|c|c|}
\hline Primer & Sequence $\left(5^{\prime}-3^{\prime}\right)$ & $\begin{array}{l}\text { Annealing } \\
\text { temp }\left({ }^{\circ} \mathrm{C}\right)\end{array}$ & Target & References \\
\hline $202 \mathrm{~F}$ & GACCAAAGGGGGCGAGCG & $55-64$ & NC10 bacterial 16S rRNA & Ettwig et al. (2009) \\
\hline 630R & CAKAAAGGAGGTGATCC & & & Juretschko et al. (1998) \\
\hline $\begin{array}{l}\text { p1F } \\
\text { p1R }\end{array}$ & $\begin{array}{l}\text { GGGCTTGACATCCCACGAACCTG } \\
\text { CGCCTTCCTCCAGCTTGACGC }\end{array}$ & 63 & NC10 bacterial 16S rRNA & Ettwig et al. (2009) \\
\hline $\begin{array}{l}\mathrm{p} 2 \mathrm{~F} \\
\mathrm{p} 2 \mathrm{R}\end{array}$ & $\begin{array}{l}\text { GGGGAACTGCCAGCGTCAAG } \\
\text { CTCAGCGACTTCGAGTACAG }\end{array}$ & 63 & NC10 bacterial 16S rRNA & Ettwig et al. (2009) \\
\hline $\begin{array}{l}\text { A189f } \\
\text { cmo682 }\end{array}$ & $\begin{array}{l}\text { GGNGACTGGGACTTYTGG } \\
\text { AAAYCCGGCRAAGAACGA }\end{array}$ & 55 & NC10 bacterial pmoA & Luesken et al. (2011) \\
\hline $\begin{array}{l}\mathrm{cmo} 182 \\
\mathrm{cmo568}\end{array}$ & $\begin{array}{l}\text { TCACGTTGACGCCGATCC } \\
\text { GCACATACTCCATCCCCATC }\end{array}$ & 59 & NC10 bacterial pmoA & Luesken et al. (2011) \\
\hline $8 \mathrm{~F}$ & AGAGTTTGATYMTGGCTCAG & 55 & All bacterial $16 \mathrm{~S}$ rRNA & Juretschko et al. (1998) \\
\hline Eub338-IR & GCTGCCTCCCGTAGGAGT & & & Amann et al. (1990) \\
\hline
\end{tabular}

study were deposited in GenBank under the accession numbers of KT355451-KT355470.

\section{Statistical analysis}

Unifrac (Hamady et al. 2009) was used to perform the principal coordinate analyses (PCoA) of the n-damo bacterial communities together with those references available in the GenBank database. Paired samples $t$ test was used for the comparison of n-damo bacterial abundance, and the correlation between n-damo bacterial abundance and environmental variables were computed by Pearson's bivariate correlation analysis conducted by PASW Statistics 18.0 (Predictive Analytics Software Statistics). The level of significance in this study was $=0.05$. Graphs were generated using ORIGIN 8.0 software.

\section{Results}

\section{Chemical profiles}

Distinct chemical profiles were found in the elevation gradient (Figure S1). The samples below the water level (sediment) showed higher concentrations of $\mathrm{NH}_{4}^{+}$being $6.1 \mathrm{mg} \mathrm{kg}^{-1}$ in 2013 and $12.4 \mathrm{mg} \mathrm{kg}^{-1}$ in 2014 on average. In contrast, the average concentrations of $\mathrm{NH}_{4}{ }^{+}$in samples above the water level (soil) were only 1.5 and $1.6 \mathrm{mg} \mathrm{kg}^{-1}$ in 2013 and 2014 , respectively. The $\mathrm{NO}_{2}{ }^{-}$concentration was below the detection limit $\left(0.01 \mathrm{mg} \mathrm{kg}^{-1}\right)$ in all samples. The content of $\mathrm{NO}_{3}{ }^{-}$ varied from 1.1 to $3.4 \mathrm{mg} \mathrm{kg}^{-1}$ with little impact observed from the water flooding. The OM which was $3.3 \%$ on average at six elevations also increased in 2014 to $5.0 \%$. However, no significant difference of OM was observed between sediment and soil samples. The $\mathrm{pH}$ values were also affected by water flooding; the average $\mathrm{pH}$ values in flooded sediments were 7.8 and 7.6 compared to 6.7 and 7.0 in soil samples of 2013 and 2014 , respectively.

The water flooding strongly influenced the $\mathrm{Fe}^{2+} / \mathrm{Fe}^{3+}$ ratio which appears to be a good indicator of the redox potential. The ratio showed a large increase after flooding. In addition, total iron concentrations of sediment samples were 4.7 times higher on average than those in soil samples. The $\mathrm{Fe}^{2+}$ concentrations were 36.3 and 35.4 times higher in sediment samples compared to soil samples in 2013 and 2014, respectively.

\section{Phylogenetic analysis of n-damo bacterial sequences}

Both the 16S rRNA and functional pmoA genes were amplified to investigate the community structure of n-damo bacteria (Table 2). All 12 samples showed positive products when targeting the $16 \mathrm{~S}$ rRNA gene, and the PCR products from the $155-\mathrm{m}$ elevation and another two samples at $160 \mathrm{~m}$ (sediment) and $170 \mathrm{~m}$ (soil) were cloned and sequenced for comparison. The coverages of the $16 \mathrm{~S}$ rRNA and pmo $A$ genes libraries ranged from 0.94 to 1.00 and from 0.99 to 1.00 , respectively, indicating that sequencing effort covered significant amounts of the richness in the samples examined.

A total of 66 to 70 randomly picked clones of each sample were sequenced. According to the previous phylogenetic analysis of n-damo bacterial sequences (Ettwig et al. 2009), all the 16S rRNA sequences retrieved from the WLFZ clustered into groups $\mathrm{a}$ and $\mathrm{b}$ (Fig. 2). Well-characterized n-damo sequences from bioreactor enrichment (Enr-F2) (Ettwig et al. 2009) and the complete sequence from the genome of Candidatus Methylomirabilis oxyfera (Ettwig et al. 2010) were included into group a. The sequences in group a are assumed to be a true $\mathrm{n}$-damo group with proven activities. However only 1 OTU (two sequences) retrieved from the sediment sample 
Table 2 Sequence information and alpha diversity of n-damo bacteria recovered from the WLFZ of the TGR

\begin{tabular}{|c|c|c|c|c|c|c|}
\hline \multirow{4}{*}{$\begin{array}{l}\text { Elevation (m) } \\
\text { Target gene }\end{array}$} & \multicolumn{6}{|c|}{ Sampling time } \\
\hline & \multicolumn{2}{|c|}{ October 2013} & \multicolumn{4}{|l|}{ April 2014} \\
\hline & \multicolumn{2}{|l|}{155} & \multicolumn{2}{|l|}{155} & \multirow{2}{*}{$\begin{array}{l}160 \\
16 \mathrm{~S} \text { rRNA }\end{array}$} & \multirow{2}{*}{$\begin{array}{l}170 \\
16 \mathrm{~S} \text { rRNA }\end{array}$} \\
\hline & 16S rRNA & pmoA & 16S rRNA & pmoA & & \\
\hline Sequence number & 70 & 70 & 68 & 69 & 66 & 67 \\
\hline Coverage & 0.94 & 1.00 & 0.99 & 0.99 & 0.97 & 1.00 \\
\hline OTU number & 7 & 1 & 4 & 4 & 4 & 3 \\
\hline Shannon & 0.95 & 0 & 0.08 & 0.97 & 0.23 & 0.23 \\
\hline
\end{tabular}

of $155 \mathrm{~m}$ in 2013 clustered into group a. All remaining sequences, including 13 OTUs with 268 sequences from this study clustered into group b, distantly related to Candidatus Methylomirabilis oxyfera. Some clones from environmental samples like ditch sediment, used as inoculum for n-damo enrichment (Ino-F1) (Ettwig et al. 2009), and costal wetland sediment (Chen et al. 2015b) also clustered into group b.
Using a nested PCR approach, n-damo pmoA gene sequences were recovered from the WLFZ samples with coverages of more than 0.95 (Table 2). Positive PCR results were obtained only with sediment samples from $155 \mathrm{~m}$ taken in 2013 and 2014. Combined with the reference sequences, the pmoA OTUs in WLFZ clustered into three groups. The only OTU of 2013 and three OTUs of 2014
Fig. 2 Phylogenetic tree showing the affiliation and distribution of n-damo bacterial 16S rRNA gene sequences retrieved from the WLFZ of the TGR. The numbers at the nodes were the levels of bootstrap support based on 1000 replicates, and only percentages more than $50 \%$ are shown. The sequence number of each OTU and total sequence number in the sample are indicated in the bracket. Sampling time and elevation are included in the clone name

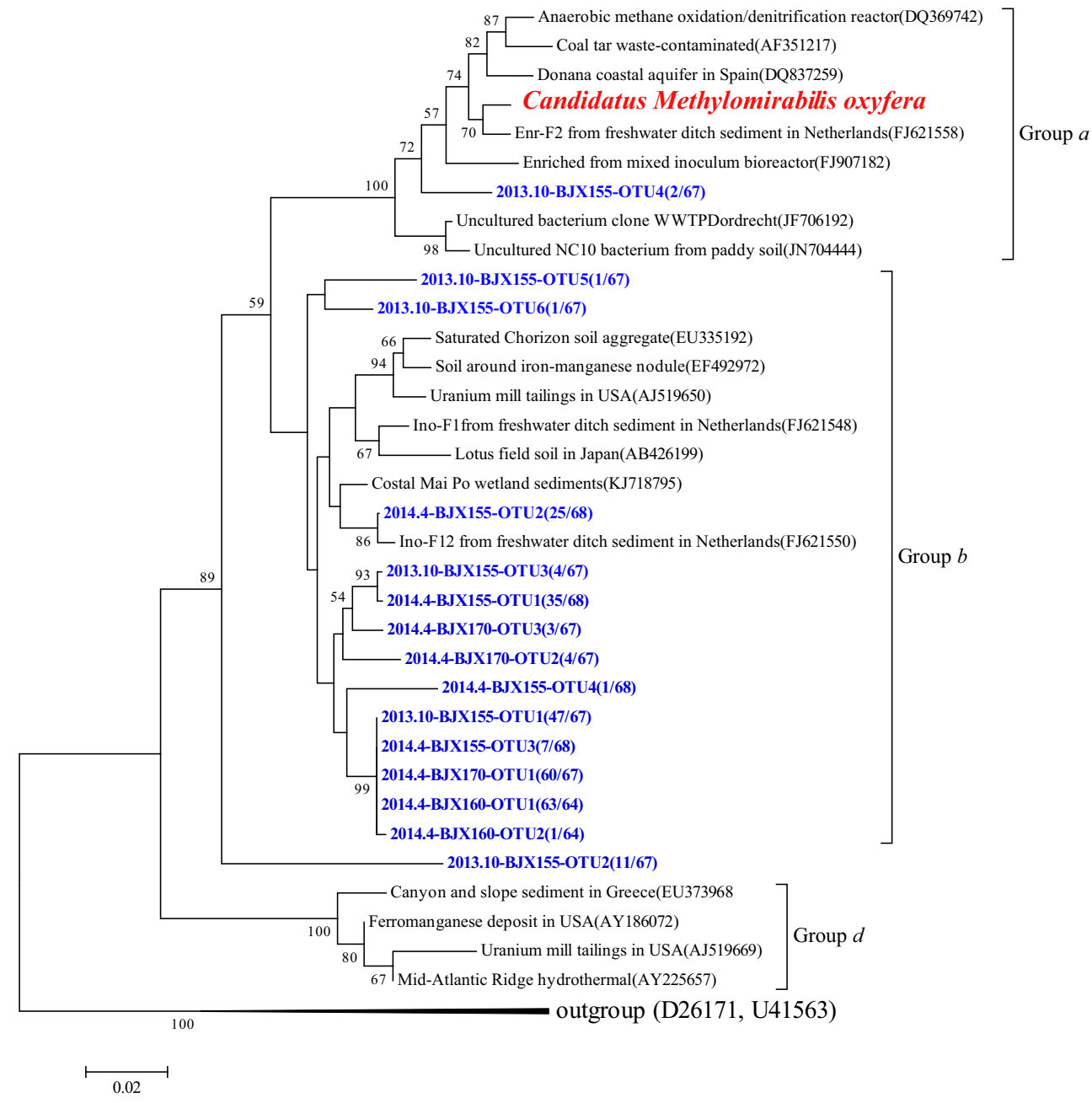


were closely related to the clones retrieved from different freshwater sediments in China. The remaining OTU clustered with sequences retrieved from paddy soil and lake sediments (Fig. 3).

\section{Diversity and community analysis of n-damo bacteria}

The diversity indexes of n-damo bacterial $16 \mathrm{~S}$ rRNA and pmoA genes in each sample are listed in Table 2. The highest diversity based on 16S rRNA gene sequences was observed in the sediment sample $(155 \mathrm{~m})$ of 2013 before water flooding, in which seven OTUs were observed with a Shannon index of 0.95 . However, the diversity of the sample from the same position in 2014 was not as high as in 2013 with 4 OTUs observed and a Shannon index of 0.08 . On the contrary, the diversity analysis based on the pmoA gene showed a higher diversity in 2014 with 4 OTUs observed and only 1 OTU in 2013.

The community structure of n-damo bacteria in the WLFZ of the TGR was investigated both on 16S rRNA and pmoA gene levels (Fig. 4). The 16S rRNA gene-based analyses showed that most of the sequences clustered with the environmental sequences in different habitats which were grouped into group b. Only 1 OTU was grouped with the $M$. oxyfera as the best-characterized n-damo cluster and 1 OTU scattered between the Three Gorges cluster and the n-damo cluster. The pmoA gene-based analyses showed that all the sequences from the WLFZ of the TGR clustered together with the sequences from natural environment such as lake sediment (Zhou et al. 2014; Zhu et al. 2015) and paddy soil (Wang et al. 2012), distantly

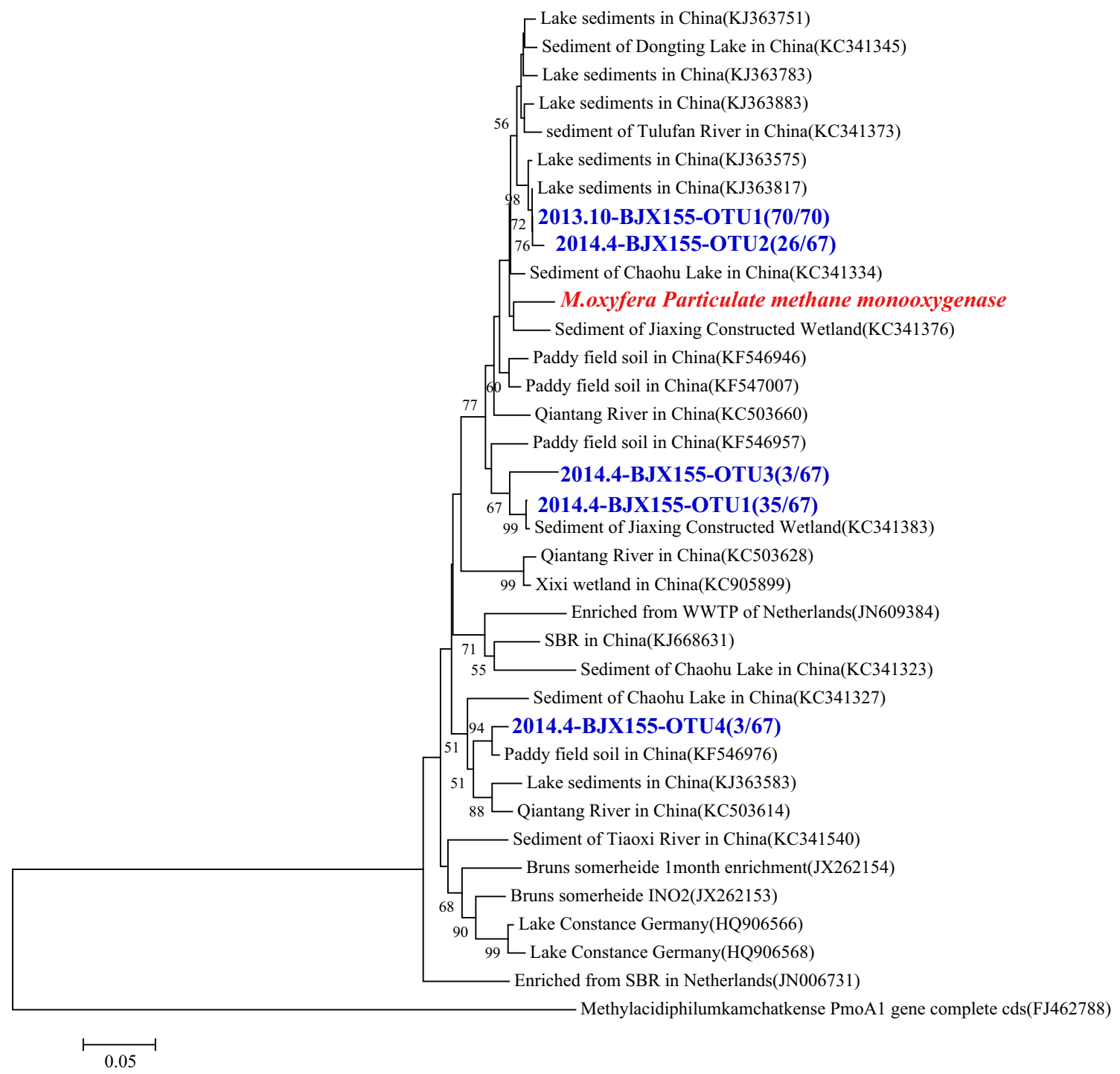

Fig. 3 Phylogenetic tree showing the affiliation and distribution of $\mathrm{n}$ damo bacterial pmoA gene sequences retrieved from the WLFZ of the TGR. The numbers at the nodes are the levels of bootstrap support based sequence number of each OTU and total sequence number in the sample are indicated in the bracket. Sampling time and elevation are included in the clone name 

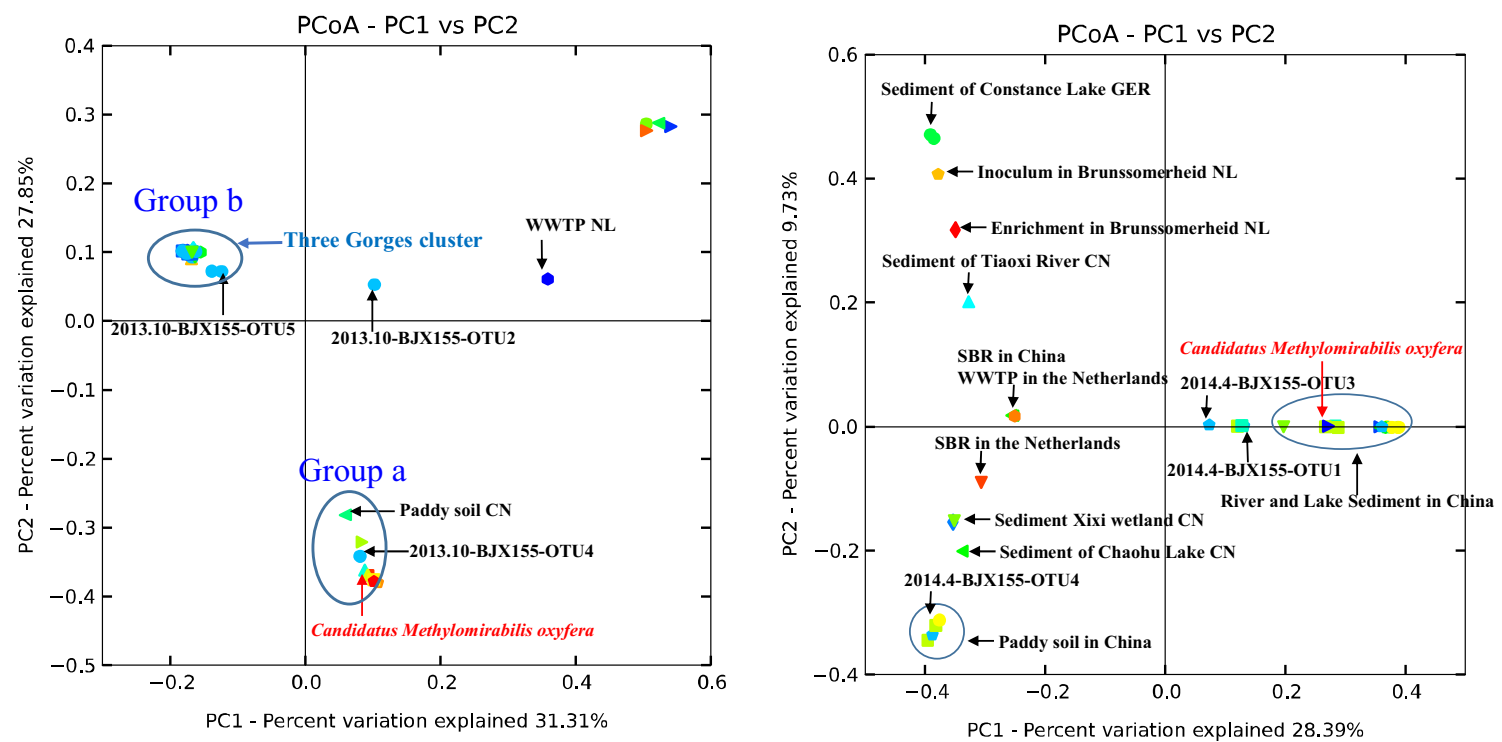

Fig. 4 Ordination diagram of the UniFrac normalized PCoA analysis of the n-damo bacterial communities using the 16S rRNA (left) and pmoA (right) genes sequences

related to the sequences from culture environments either in China (Hu et al. 2014b) or The Netherlands (Wang et al. 2012). Compared with the pmoA sequences from The Netherlands (Zhu et al. 2012) and Germany (Deutzmann et al. 2014), sequences obtained in this study were more likely to cluster with the environmental samples from China (Shen et al. 2015; Zhou et al. 2014; Zhu et al. 2015).

\section{Abundance of n-damo bacteria}

The abundance of $\mathrm{n}$-damo bacteria was estimated by quantifying the 16S rRNA gene using two primer pairs (Fig. 5). The results from primer pair $\mathrm{p} 1 \mathrm{~F}-\mathrm{p} 1 \mathrm{R}$ showed slightly higher abundances than those of $\mathrm{p} 2 \mathrm{~F}-\mathrm{p} 2 \mathrm{R}$, in agreement with a previous study (Ettwig et al. 2009). However, results from the two primer pairs showed similar variations. Hence, the average values of two primer pairs were used in the following analysis.

The n-damo copy numbers varied from $4.7 \times 10^{2}$ to $1.5 \times$ $10^{3}$ copies $\mathrm{g}^{-1}$ dry soil (ds) before the water flooding in 2013. Higher copy numbers were observed after water flooding in 2014 , ranging from $3.2 \times 10^{3}$ to $5.3 \times 10^{4}$ copies $\mathrm{g}^{-1} \mathrm{ds}$. It was noted that the abundances in sediment samples were $1.0 \times$ $10^{3}$ and $4.9 \times 10^{4}$ copies $\mathrm{g}^{-1}$ ds on average in 2013 and 2014, respectively, being consistently higher than the abundances in
Fig. 5 Abundance of n-damo bacteria in samples of different elevations in 2013 (left) and 2014 (right). The light blue background indicates the samples below the water level. Two primer pairs including p1F-p1R (P1) and $\mathrm{p} 2 \mathrm{~F}-\mathrm{p} 2 \mathrm{R}(\mathrm{P} 2)$ were used for the quantification of $\mathrm{n}$-damo bacteria ( $x$-axis at the bottom). Three samples in 2014 which were significantly higher than others were marked with stars. The abundance of total bacteria is implied in dots and line ( $x$-axis at the top). Error bars indicate standard deviation $(n=3)$

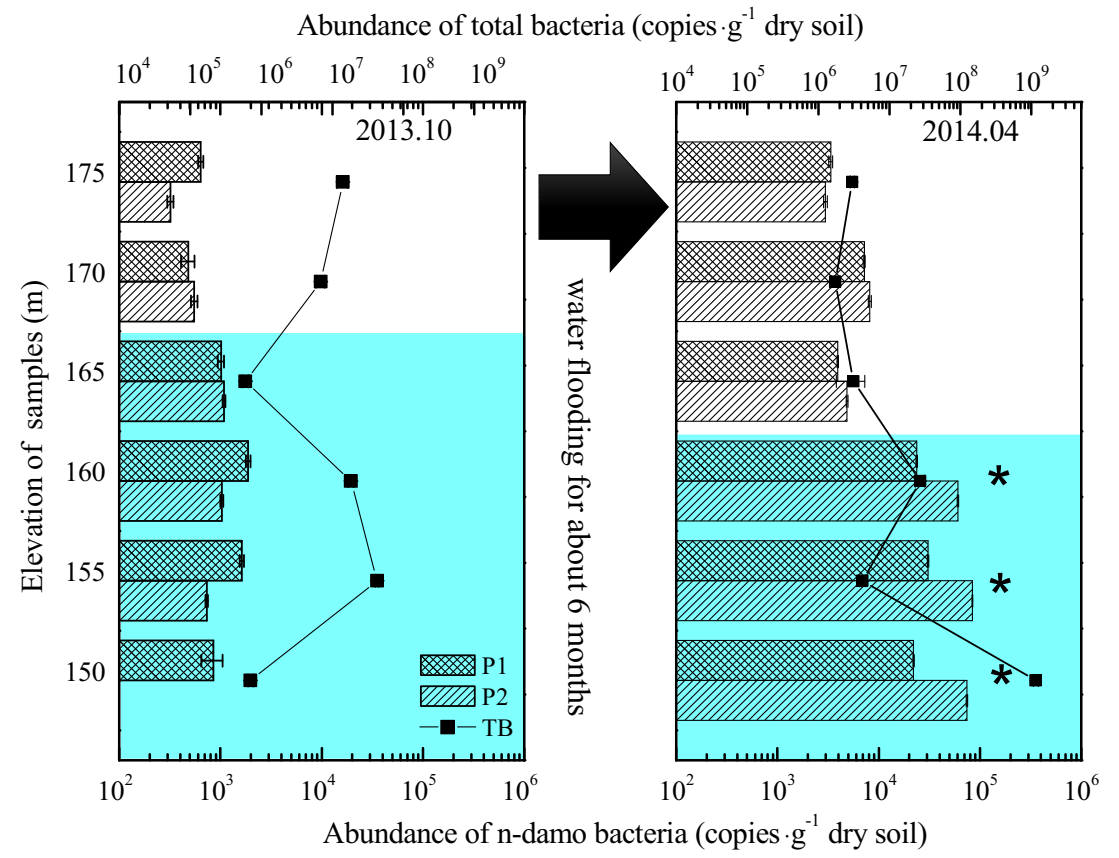


soil samples $\left(5.0 \times 10^{2}\right.$ and $5.1 \times 10^{3}$ copies $^{-1}$ ds in 2013 and 2014). Three sediments samples from 2014 at 150-, 155-, and $160-\mathrm{m}$ elevations were significantly higher than the others. The total bacteria were also quantified to demonstrate the general variation of bacterial abundance. The abundance of total bacteria in 2013 ranged from $5.9 \times 10^{5}$ to $4.3 \times 10^{7}$ copies $\mathrm{g}^{-1}$ ds and from $1.7 \times 10^{6}$ to $1.2 \times 10^{9}$ copies $^{-1}$ ds in 2014. Unlike the variation of $n$-damo bacteria, no significant difference of total bacterial abundance was observed between the two years. The only significant higher value was from sediment sample taken at 150-m elevation in 2014.

To elucidate the potential influencing factors to the distribution of n-damo bacteria, statistical analyses were performed between the abundance and environmental variables. Among the various physicochemical variables, the abundance positively correlated with the $\mathrm{C} / \mathrm{N}$ ratio (Pearson correlation coefficient $=0.598, n=12, P<0.05$ ). Notably, the abundance also correlated positively with the accumulated flooding time (AFT) and the coefficients increased from $0.675(P<0.05), 0.720$ $(P<0.01)$, and $0.795(P<0.01)$ to $0.933(P<0.01)$ when the AFT was calculated from June samples of 2010, 2011, 2012, and 2013, respectively (Table 3).

\section{Discussion}

M. oxyfera-like bacteria have been demonstrated to be widely distributed in stable environments such as freshwater sediment

\begin{tabular}{lll}
$\begin{array}{l}\text { Table } 3 \text { Correlation } \\
\text { coefficient between the } \\
\text { abundance of n-damo } \\
\text { bacterial 16S rRNA gene } \\
\text { and physicochemical } \\
\text { properties and }\end{array}$ & $\begin{array}{l}\text { Correlations with } \\
\text { the abundance of } \\
\text { n-damo bacteria }\end{array}$ \\
\cline { 2 - 3 } $\begin{array}{l}\text { accumulated flooding } \\
\text { time (AFT) of the WLFZ } \\
\text { in the TGR }\end{array}$ & $\mathrm{NH}_{4}^{+}$ & -0.443 \\
& $\mathrm{Ne}_{2}{ }^{+}$ & -0.478 \\
& $\mathrm{Fe}_{3}{ }^{+}$ & -0.353 \\
& $\mathrm{Fe}_{2}{ }^{+} / \mathrm{Fe}_{3}{ }^{+}$ & -0.185 \\
& $\mathrm{OM}$ & -0.207 \\
& $\mathrm{C} / \mathrm{N}$ & -0.046 \\
& $\mathrm{TN}$ & $0.598^{*}$ \\
& $\mathrm{TS}$ & -0.316 \\
& $\mathrm{TC}$ & $-0.659^{*}$ \\
& $\mathrm{pH}$ & -0.074 \\
& $\mathrm{ST}-10.6$ & -0.437 \\
& $\mathrm{ST}-11.6$ & $0.675^{*}$ \\
$\mathrm{ST}-12.6$ & $0.720^{* *}$ \\
$\mathrm{ST}-13.6$ & $0.795^{* *}$ \\
& & $0.897^{* *}$ \\
& &
\end{tabular}

ST-10.6, 11.6, 12.6, and 13.6 represented the AFT (days) since June of 2010, 2011, 2012, and 2013 to the sampling time

Numbers in italics were regarded as significant $\left(P\right.$ less than $0.01^{* *}$ or $\left.0.05^{*}\right)$
(Deutzmann et al. 2014; Hu et al. 2014a; Norði and Thamdrup 2014) and WWTP sludge (Hu et al. 2014b; Luesken et al. 2011). Here, we conducted a study in a water-level fluctuation zone of a reservoir with seasonal flooding.

The presence of n-damo bacteria was verified using molecular methods. However, the community composition of $n-$ damo bacteria differed substantially between sites. In the samples taken from six elevations at two different sampling times, molecular evidence showed n-damo bacteria were more likely to be observed at lower elevations, suggesting the lower sites which endured longer flooding time and as a consequence anoxic conditions could be a preferred habitat for $M$. oxyfera-like bacteria. The results were consistent with previous studies showing that the distribution of $M$. oxyfera-like bacteria was restricted by the presence of $\mathrm{O}_{2}$ in natural ecosystems and higher abundances in deeper sediments (Deutzmann et al. 2014; Kojima et al. 2012) and deep wetland soils (Hu et al. 2014a; Wang et al. 2012; Zhou et al. 2014; Zhu et al. 2015). Unlike other studies, nitrite was not detected in our samples. The low level of nitrite may be explained by a high turnover rate. It was hypothesized that $\mathrm{n}$-damo bacteria cooperated with denitrifying bacteria which reduce nitrate to nitrite or with ammonium oxidizing bacteria (Hu et al. 2011; Zhu et al. 2010). In this case, the higher content of ammonium in lower sites suggested a high possibility of the cooperation between n-damo bacteria and ammonium oxidizing bacteria or archaea.

A relatively low level of diversity was observed in this study; only 1 and 4 OTUs were recovered from 70 and 67 pmoA gene sequences, respectively. This is in agreement with previous studies in paddy soil (Wang et al. 2012), freshwater reservoir, reed bed, and sludge from a wastewater treatment plant (Han and Gu 2013). In contrast, other studies reported higher diversities in river sediments influenced by tides (Shen et al. 2014b) and in the soil/groundwater ecotone of paddy soil (Zhou et al. 2014). The more dynamic environmental conditions could provide diverse micro-environments for different species of M. oxyfera-like bacteria (Shen et al. 2014b). In our study, the disturbance in the WLFZ was apparently too strong to maintain a high diversity. The detected diversities were different targeting the 16S rRNA and pmoA genes, which has been repetitively observed (Chen et al. 2014; Chen et al. 2015b; Shen et al. 2014a). This may be due to the bias of the $16 \mathrm{~S}$ rRNA and $p m o A$ genes primers, which were originally designed based on limited references of $M$. oxyfera-like bacteria (Ettwig et al. 2009).

The copy number of $n$-damo bacteria at the initial stage of water flooding ranged from $4.7 \times 10^{2}$ to $1.5 \times 10^{3}$ copies $^{-1} \mathrm{ds}$ which were almost the lowest reported abundances comparing with lake sediments from Japan $\left(10^{5}\right.$ to $10^{6}$ copies $\left.\mathrm{g}^{-1} \mathrm{ds}\right)$ (Kojima et al. 2012) and China $\left(10^{5}\right.$ to $10^{6}$ copies $\left.\mathrm{g}^{-1} \mathrm{ds}\right)$ (Shen et al. 2014b), freshwater wetland $\left(10^{3}\right.$ to $10^{7}$ copies $\mathrm{g}^{-1}$ ds) (Zhu et al. 2015) and costal wetland $\left(10^{5}\right.$ copies $\left.\mathrm{g}^{-1} \mathrm{ds}\right)$ 
(Chen et al. 2015b). However, an increase was observed after nearly 6 months flooding in $2014\left(3.2 \times 10^{3}\right.$ to $5.3 \times 10^{4}$ copies $\mathrm{g}^{-1} \mathrm{ds}$ ), showing the positive effect of water flooding to the n-damo bacterial population. The carbon and nitrogen availability were usually the decisive factors for the ndamo bacterial community. It was reported that the potential ndamo rates were mostly affected by the availability of $\mathrm{NO}_{2}{ }^{-}$and $\mathrm{NO}_{3}{ }^{-}$(Norði and Thamdrup 2014) and the $\mathrm{NO}_{x}{ }^{-}$concentration influenced the community structures and distribution of M. oxyfera-like bacteria (Chen et al. 2015b). The concentration of soil organic carbon was also observed to show a significant impact on the distribution of n-damo bacteria (Wang et al. 2012; Zhou et al. 2014). However, no significant correlation was observed between n-damo bacterial abundance and any nitrogenor carbon-related chemical parameter in this study. Interestingly, the abundance of $\mathrm{n}$-damo bacteria significantly correlated with the AFT indicating a positive effect of water flooding resulting in more anaerobic conditions, on the ndamo bacterial population. Until now, not much is known about the susceptibility of n-damo bacteria to environmental changes. Limited physiological data come from enrichment cultures operated for several months before significant AOM rates were detected (Ettwig et al. 2009; Hu et al. 2011; Raghoebarsing et al. 2006). The results of this study showed that the population of $n$-damo bacteria can still grow in a natural environment after water flooding for a long time creating anoxic conditions. It was hypothesized that $\mathrm{n}$-damo bacteria depend on redox gradients at oxic-anoxic interfaces in their natural environments (Zhu et al. 2010). In addition, our results showed that the anaerobic condition and availability of ammonium would be of great significance to n-damo bacteria.

In conclusion, the WLFZ of the TGR do not provide a stable habitat for n-damo bacteria due to the periodic exposure to air when water levels drop. However, they still can be detected at lower elevations suggesting the wide range of habitat in nature and thus high potential to play a key role in natural $\mathrm{CH}_{4}$ consumption. The $\mathrm{CH}_{4}$ emission of the Three Gorge Reservoir had long been concerned (Qiu 2009). Recent evidence showed the $\mathrm{CH}_{4}$ emission in the Three Gorge Reservoir maintained in the low range of reported fluxes in similar reservoirs globally (Xiao et al. 2013) and 51.8 to $77.4 \%$ of the methane was oxidized anaerobically in the sediment (Wang et al. 2014). Although no direct evidence linked the $\mathrm{CH}_{4}$ oxidation to any microbial process in the Three Gorge Reservoir, the n-damo process would take over most of the anaerobic methane oxidation according to previous studies in freshwater systems (Deutzmann et al. 2014; Hu et al. 2014a; Norði and Thamdrup 2014).

Acknowledgments This research is financially supported by the National Natural Science Foundation of China (No. 41303053), Fundamental and Frontier Research Project of Chongqing (No. cstc2013jcyjA20003), West
Light Foundation, and West China Action Plan of the Chinese Academy of Sciences (No. KZCX2-XB3-14-01).

Compliance with ethical standards This article does not contain any studies with animals performed by any of the authors.

Conflict of interest The authors declare that they have no competing interests.

\section{References}

Amann RI, Binder BJ, Olson RJ, Chisholm SW, Devereux R, Stahl DA (1990) Combination of 16S rRNA-targeted oligonucleotide probes with flow cytometry for analyzing mixed microbial populations. Appl Environ Microbiol 56(6):1919-1925

Bao S (2005) The method of the soil and agriculture chemical analysis [M]. China Agriculture Press, Beijing

Beal EJ, House CH, Orphan VJ (2009) Manganese- and iron-dependent marine methane oxidation. Science 325(5937):184-187. doi:10. 1126/science. 1169984

Boetius A, Ravenschlag K, Schubert CJ, Rickert D, Widdel F, Gieseke A, Amann R, Jorgensen BB, Witte U, Pfannkuche O (2000) A marine microbial consortium apparently mediating anaerobic oxidation of methane. Nature 407(6804):623-626. doi:10.1038/35036572

Chen J, Jiang X-W, Gu J-D (2015a) Existence of novel phylotypes of nitrite-dependent anaerobic methane-oxidizing bacteria in surface and subsurface sediments of the South China Sea. Geomicrobiol J 32(1):1-10. doi:10.1080/01490451.2014.917742

Chen J, Zhou Z-C, Gu J-D (2014) Occurrence and diversity of nitritedependent anaerobic methane oxidation bacteria in the sediments of the South China Sea revealed by amplification of both 16S rRNA and pmoA genes. Appl Microbiol Biotechnol 98(12):5685-5696. doi:10.1007/s00253-014-5733-4

Chen J, Zhou Z, Gu J-D (2015b) Complex community of nitritedependent anaerobic methane oxidation bacteria in coastal sediments of the Mai Po wetland by PCR amplification of both $16 \mathrm{~S}$ rRNA and pmoA genes. Appl Microbiol Biotechnol 99(3):14631473. doi:10.1007/s00253-014-6051-6

China Three Gorges Corporation (2015) Introduction of Three Gorges Corporation (in Chinese). PUblisher. http://www.ctgpc.com.cn/ sxgc/newsdetail2.php

Dalsgaard T, Thamdrup B, Canfield DE (2005) Anaerobic ammonium oxidation (anammox) in the marine environment. Res Microbiol 156(4):457-464. doi:10.1016/j.resmic.2005.01.011

Deutzmann JS, Stief P, Brandes J, Schink B (2014) Anaerobic methane oxidation coupled to denitrification is the dominant methane sink in a deep lake. P Natl Acad Sci USA 111(51):18273-18278. doi:10. 1073/pnas. 1411617111

Ettwig KF, Butler MK, Le Paslier D, Pelletier E, Mangenot S, Kuypers MMM, Schreiber F, Dutilh BE, Zedelius J, de Beer D, Gloerich J, Wessels HJCT, van Alen T, Luesken F, Wu ML, van de Pas-Schoonen KT, den Camp HJMO, Janssen-Megens EM, Francoijs KJ, Stunnenberg H, Weissenbach J, Jetten MSM, Strous M (2010) Nitrite-driven anaerobic methane oxidation by oxygenic bacteria. Nature 464(7288):543-548. doi: 10.1038 /nature 08883

Ettwig KF, van Alen T, van de Pas-Schoonen KT, Jetten MSM, Strous M (2009) Enrichment and molecular detection of denitrifying methanotrophic bacteria of the NC10 phylum. Appl Environ Microb 75(11):3656-3662. doi:10.1128/Aem.00067-09 
Hamady M, Lozupone C, Knight R (2009) Fast UniFrac: facilitating high-throughput phylogenetic analyses of microbial communities including analysis of pyrosequencing and PhyloChip data. ISME J 4(1):17-27. doi:10.1038/ismej.2009.97

Han P, Gu J-D (2013) A newly designed degenerate PCR primer based on рто $A$ gene for detection of nitrite-dependent anaerobic methaneoxidizing bacteria from different ecological niches. Appl Microbiol Biotechnol 97(23):10155-10162. doi:10.1007/s00253013-5260-8

Haroon MF, Hu S, Shi Y, Imelfort M, Keller J, Hugenholtz P, Yuan Z, Tyson GW (2013) Anaerobic oxidation of methane coupled to nitrate reduction in a novel archaeal lineage. Nature 500(7464):567570. doi:10.1038/nature 12375

Hu B-L, Shen L-D, Lian X, Zhu Q, Liu S, Huang Q, He Z-F, Geng S, Cheng D-Q, Lou L-P, Xu X-Y, Zheng P, He Y-F (2014a) Evidence for nitrite-dependent anaerobic methane oxidation as a previously overlooked microbial methane sink in wetlands. P Natl Acad Sci USA 111(12):4495-4500. doi:10.1073/pnas.1318393111

Hu B, He Z, Geng S, Cai C, Lou L, Zheng P, Xu X (2014b) Cultivation of nitrite-dependent anaerobic methane-oxidizing bacteria: impact of reactor configuration. Appl Microbiol Biotechnol 98(18):79837991. doi:10.1007/s00253-014-5835-Z

Hu S, Zeng RJ, Keller J, Lant PA, Yuan Z (2011) Effect of nitrate and nitrite on the selection of microorganisms in the denitrifying anaerobic methane oxidation process. Environ Microbiol Rep 3(3):315319. doi:10.1111/j.1758-2229.2010.00227.x

Joabsson A, Christensen TR, Wallén B (1999) Vascular plant controls on methane emissions from northern peatforming wetlands. Trends Ecol Evol 14(10):385-388. doi:10.1016/S0169-5347(99)01649-3

Juretschko S, Timmermann G, Schmid M, Schleifer KH, PommereningRoser A, Koops HP, Wagner M (1998) Combined molecular and conventional analyses of nitrifying bacterium diversity in activated sludge: Nitrosococcus mobilis and Nitrospira-like bacteria as dominant populations. Appl Environ Microb 64(8):3042-3051

Kojima H, Tsutsumi M, Ishikawa K, Iwata T, Mußmann M, Fukui M (2012) Distribution of putative denitrifying methane oxidizing bacteria in sediment of a freshwater lake, Lake Biwa. Syst Appl Microbiol 35(4):233-238. doi:10.1016/j.syapm.2012.03.005

Luesken FA, Zhu BL, van Alen TA, Butler MK, Diaz MR, Song B, den Camp HJMO, Jetten MSM, Ettwig KF (2011) pmoA primers for detection of anaerobic methanotrophs. Appl Environ Microb 77(11):3877-3880. doi:10.1128/aem.02960-10

Milucka J, Ferdelman TG, Polerecky L, Franzke D, Wegener G, Schmid M, Lieberwirth I, Wagner M, Widdel F, Kuypers MMM (2012) Zero-valent sulphur is a key intermediate in marine methane oxidation. Nature 491(7425):541-546. doi:10.1038/nature11656

Norði K, Thamdrup B (2014) Nitrate-dependent anaerobic methane oxidation in a freshwater sediment. Geochim Cosmochim Acta 132: 141-150. doi:10.1016/j.gca.2014.01.032

Qiu J (2009) Chinese dam may be a methane menace: wetlands around Three Gorges produce tonnes of the greenhouse gas. Nature. doi: 10 . 1038/news.2009.962

Raghoebarsing AA, Pol A, Van de Pas-Schoonen KT, Smolders AJ, Ettwig KF, Rijpstra WIC, Schouten S, Damsté JSS, den Camp HJO, Jetten MS (2006) A microbial consortium couples anaerobic methane oxidation to denitrification. Nature 440(7086):918-921. doi:10.1038/nature04617

Rudd JW, Hecky R, Harris R, Kelly C (1993) Are hydroelectric reservoirs significant sources of greenhouse gases ? Ambio 22:246-248

Schloss PD, Westcott SL, Ryabin T, Hall JR, Hartmann M, Hollister EB, Lesniewski RA, Oakley BB, Parks DH, Robinson CJ, Sahl JW, Stres B, Thallinger GG, Van Horn DJ, Weber CF (2009) Introducing mothur: open-source, platform-independent, community-supported software for describing and comparing microbial communities. Appl Environ Microb 75(23):7537-7541. doi:10.1128/aem.0154109

Shen L-D, Wu H-S, Gao Z-Q (2015) Distribution and environmental significance of nitrite-dependent anaerobic methane-oxidising bacteria in natural ecosystems. Appl Microbiol Biotechnol 99(1):133142. doi:10.1007/s00253-014-6200-y

Shen L-D, Zhu Q, Liu S, Du P, Zeng J-N, Cheng D-Q, Xu X-Y, Zheng P, Hu B-L (2014a) Molecular evidence for nitrite-dependent anaerobic methane-oxidising bacteria in the Jiaojiang Estuary of the East Sea (China). Appl Microbiol Biotechnol 98(11):5029-5038. doi:10. 1007/s00253-014-5556-3

Shen LD, Liu S, Zhu Q, Li XY, Cai C, Cheng DQ, Lou LP, Xu XY, Zheng $\mathrm{P}, \mathrm{Hu} \mathrm{BL}(2014 \mathrm{~b})$ Distribution and diversity of nitrite-dependent anaerobic methane-oxidising bacteria in the sediments of the Qiantang River. Microb Ecol 67(2):341-349. doi:10.1007/s00248013-0330-0

Solomon S, Qin D, Manning M, Chen Z, Marquis M, Averyt K, Tignor M, Miller H (2007) IPCC, 2007: climate change 2007: the physical science basis. Contribution of Working Group I to the fourth assessment report of the Intergovernmental Panel on Climate Change

St. Louis VL, Kelly CA, Duchemin É, Rudd JWM, Rosenberg DM (2000) Reservoir surfaces as sources of greenhouse gases to the atmosphere: a global estimate. Bioscience 50(9):766-775. doi:10. 1641/0006-3568(2000)050[0766:rsasog]2.0.co;2

Tamura K, Peterson D, Peterson N, Stecher G, Nei M, Kumar S (2011) MEGA5: molecular evolutionary genetics analysis using maximum likelihood, evolutionary distance, and maximum parsimony methods. Mol Biol Evol 28(10):2731-2739. doi:10.1093/molbev/ msr121

Thauer RK, Shima S (2008) Methane as fuel for anaerobic microorganisms. Ann N Y Acad Sci 1125(1):158-170. doi:10.1196/annals. 1419.000

Wang C, Xiao S, Li Y, Zhong H, Li X, Peng F (2014) Methane formation and consumption processes in Xiangxi Bay of the Three Gorges Reservoir. Sci Rep 4. doi:10.1038/srep04449

Wang Y, Zhu G, Harhangi HR, Zhu B, Jetten MSM, Yin C, Op den Camp HJM (2012) Co-occurrence and distribution of nitrite-dependent anaerobic ammonium and methane-oxidizing bacteria in a paddy soil. FEMS Microbiol Lett 336(2):79-88. doi:10.1111/j.15746968.2012.02654.x

Xiao S, Liu D, Wang Y, Yang Z, Chen W (2013) Temporal variation of methane flux from Xiangxi Bay of the Three Gorges Reservoir. Sci Rep 3. doi:10.1038/srep02500

Zhou L, Wang Y, Long XE, Guo J, Zhu G (2014) High abundance and diversity of nitrite-dependent anaerobic methane-oxidizing bacteria in a paddy field profile. FEMS Microbiol Lett 360(1):33-41. doi:10. 1111/1574-6968.12567

Zhu B, van Dijk G, Fritz C, Smolders AJP, Pol A, Jetten MSM, Ettwig KF (2012) Anaerobic oxidization of methane in a minerotrophic peatland: enrichment of nitrite-dependent methane-oxidizing bacteria. Appl Environ Microb 78(24):8657-8665. doi:10.1128/aem. 02102-12

Zhu G, Jetten MM, Kuschk P, Ettwig K, Yin C (2010) Potential roles of anaerobic ammonium and methane oxidation in the nitrogen cycle of wetland ecosystems. Appl Microbiol Biotechnol 86(4):10431055. doi:10.1007/s00253-010-2451-4

Zhu G, Zhou L, Wang Y, Wang S, Guo J, Long X-E, Sun X, Jiang B, Hou Q, Jetten MSM, Yin C (2015) Biogeographical distribution of denitrifying anaerobic methane oxidizing bacteria in Chinese wetland ecosystems. Environ Microbiol Rep 7(1):128-138. doi:10. $1111 / 1758-2229.12214$ 